\title{
Compensatory nutrition-directed mammary cell proliferation and lactation in rats
}

\author{
S. H. Kim ${ }^{1}$, Y. S. Moon ${ }^{2}$, W. L. Keller ${ }^{3}$ and C. S. Park ${ }^{3 *}$ \\ ${ }^{1}$ Department of Oncology/Cell Biology, Albert Einstein College of Medicine, Bronx, NY 10461, USA \\ ${ }^{2}$ Department of Nutritional Sciences, University of California, Berkeley, CA 94720, USA \\ ${ }^{3}$ Department of Animal and Range Sciences, North Dakota State University, Fargo, ND 58105, USA
}

(Received 10 March 1997 - Revised 11 August 1997 - Accepted 14 August 1997)

\begin{abstract}
The proper use of a time-dependent and controlled nutrition regimen during the hormonesensitive growth phase before first parturition can significantly affect mammary growth and subsequent lactation performance. The objective of the present study was to determine if a compensatory nutrition regimen improves lactation performance by affecting proliferation and apoptosis of mammary epithelial cells. Forty female rats ( 7 weeks of age, average weight $148 \mathrm{~g}$ ) were assigned to either (1) control, free access to diet or (2) stair-step compensatory nutrition regimen, an alternating 3-4-week schedule beginning with an energy-restricted diet $(31.2 \%$ restriction) for 3 weeks, followed by the control diet for 4 weeks. Estimated milk yield was greater $(P<0.05)$ on day 15 of lactation in the compensatory nutrition group than in the control group. Mammary cell proliferation values were 1.4 - and 2.7 -fold greater in mammary tissue from the compensatory group during pregnant and early lactating stages respectively, compared with those from the control group. Ornithine decarboxylase (EC 4.1.1.17) mRNA was $24 \%$ higher $(P<0.05)$ in mammary tissues of rats from the compensatory nutrition group during pregnancy than in those from the control group. These results indicate that the compensatory nutrition regimen imposed during the peripubertal growth phase stimulated mammary epithelial cell proliferation and improved lactation performance.
\end{abstract}

Compensatory growth: Lactation: Mammary tissue

Dietary restriction has a profound influence on the biology and health of animals including retardation of ageing and reduction of cancer incidence (Weindruch \& Walford, 1988). While imposition of excessive dietary restriction on growing animals may inhibit normal development of the mammary gland, a well-controlled dietary energy restriction regimen positively effects mammary growth, development and subsequent lactation in rats (Park et al. 1988) and bovine species (Park et al. 1989; Peri et al. 1993; Barash et al. 1994; Choi et al. 1997). The stair-step (phased) compensatory nutrition regimen proposed and studied in our laboratory is designed so that development of mammary tissues is minimal during an energy restriction phase, while a compensatory growth phase immediately following energy restriction stimulates rapid and fuller development of the mammary gland. Studies from our laboratory (Park et al. 1988, 1989, 1997), as well as from others (Barash et al. 1994; Choi et al. 1997), show that lactation performance is increased by $8-17 \%$ in animals reared on a compensatory nutrition regimen.
The cellular mechanisms responsible for the effects of nutritionally-induced compensatory growth on development, differentiation and regression of the mammary gland are not well studied despite the potentially beneficial role of a controlled nutrition regimen in improving lactation. A better understanding of how cell number is controlled may lead to strategies for prolonging lactation, not only by increasing peak yield, but also by reducing net loss of mammary cells. The objective of the present study was to determine if a compensatory nutrition regimen enhanced lactation performance by affecting proliferation and apoptosis of mammary epithelial cells in female rats.

\section{Materials and methods}

\section{Animals and diets}

Forty female Sprague-Dawley rats were obtained from Harlan Sprague-Dawley (Indianapolis, IN, USA) at 6 weeks of age. Rats were housed individually in metal wire

\footnotetext{
Abbreviations: BrdU, bromodeoxyuridine; ODC, ornithine decarboxylase; SSPE, sodium chloride-sodium dihydrogen phosphate-EDTA disodium salt; $\mathrm{TdT}$, terminal deoxynucleotidyl transferase.

*Corresponding author: Professor C. S. Park, fax +1 7012317590 , email cpark@plains.nodak.edu
} 
mesh bottomed cages and kept in an isolated room with controlled environment: $25^{\circ}$ and $50 \%$ relative humidity with $12 \mathrm{~h}$ light-dark cycle and free access to water. All experimental methods and procedures were approved by the University Animal Care and Use Committee.

Rats were acclimated to our facilities for a 1-week period. During this acclimation period, all rats were given ad libitum access to the control diet (modified AIN-76 diet; American Institute of Nutrition, 1977). At 7 weeks of age, rats weighing $120-157 \mathrm{~g}$ were randomly assigned to either control (n 20,148.4 (SE 3.8) g) or stair-step compensatory nutrition regimen ( $n$ 20,147.8 (SE 4.3) g) groups. The control group was offered free access to the control diet throughout the trial period; feed intake was recorded twice weekly and average daily intake was estimated. The compensatory nutrition group was subjected to a 3- and 4-week phased schedule beginning with an energyrestricted diet (31.2\% energy restriction) for 3 weeks followed by a re-alimentation diet (free access to control diet) for 4 weeks. The treatment diet during the energy restriction period was formulated to provide similar intakes of protein, vitamins, and minerals as the control diet but less energy (Table 1). During the energy restriction phase, treatment rats were fed on the energy-restricted diet at $60 \%$ of the average ad libitum intake of the control group: e.g. if the control group consumed $10 \mathrm{~g} / \mathrm{d}$, the amount of feed offered to the restricted group was $6 \mathrm{~g} /$ day. Thus, the overall energy intake of the compensatory nutrition rats was intended to be $13.4 \%$ less than that of the control group.

On completion of the nutrition regimen (approximately 14 weeks of age), rats were maintained on the control diet with free access for the remaining experimental period. All rats were mated during the second week of re-alimentation (11 weeks of age). The six rats that failed to conceive during the $10 \mathrm{~d}$ mating period were removed from the experiment leaving seventeen pregnant rats in each group.

Table 1. Ingredients and chemical composition of experimental diets $(\mathrm{g} / \mathrm{kg})$

\begin{tabular}{lcc}
\hline & \multicolumn{2}{c}{ Diet } \\
\cline { 2 - 3 } & Control & Energy-restricted $\dagger$ \\
\hline Ingredient* & 200 & 334 \\
Casein & 3 & 5 \\
DL-Methionine & 500 & 285 \\
Sucrose & 150 & 85 \\
Maize starch & 50 & 83.5 \\
Cellulose (Alphacel) & 50 & 129 \\
Maize oil & 35 & 58.5 \\
Mineral mix (AIN 76) $\ddagger$ & 10 & 16.7 \\
Vitamin mix (AIN 76) $\ddagger$ & 2 & 3.3 \\
Choline bitartrate & 180 & 314 \\
Chemical analysis & 18.9 & 21.7 \\
Crude protein & 17.0 & 19.5 \\
Gross energy (MJ $/ \mathrm{kg})$ & & \\
Digestible energy (MJ/kg) $\$$ & & \\
\hline
\end{tabular}

*All ingredients were purchased from ICN Biochemicals (Costa Mesa, CA, USA).

† Diet of the compensatory nutrition group during the energy restriction phase.

\pm American Institute of Nutrition (1977).

$\S$ Digestible energy $=0.9 \times$ gross energy (Nelson et al. 1974).
Litter size in both groups was adjusted to eight pups per dam on day 3 of lactation. Weights of dams and litters were measured every $2 \mathrm{~d}$ from day 3 to day 15 of lactation. Milk yield on day 15 of lactation was determined by the stepwise forward multiple regression equation from Sampson \& Jansen (1984).

\section{Immunohistochemistry}

Five randomly selected rats per treatment group were injected intraperitoneally with bromodeoxyuridine (BrdU, a

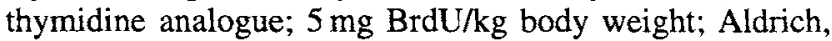
Milwaukee, WI, USA) during mid-pregnancy (day 11), and early lactation (day 3) (five control (mean litter size 10.5 (SE 0.4); litter weight 67.3 (SE 2.4) g) and five compensatory nutrition rats (mean litter size 10.7 (SE 0.5); litter weight 68.0 (SE 2.0) g)). At $2 \mathrm{~h}$ after the BrdU injection the animals were killed using $\mathrm{CO}_{2}$. Inguinal mammary tissue was removed and fixed in Carnoy's solution for $4 \mathrm{~h}$ at room temperature. Samples of mammary tissues from pregnant rats were also frozen rapidly in liquid $\mathrm{N}_{2}$, and stored at $-70^{\circ}$ for subsequent RNA extraction and Northern blot analysis. Paraffin-embedded mammary tissues were sectioned at $5 \mu \mathrm{m}$ and mounted onto glass slides using standard histological techniques. After rehydration, tissue sections were incubated in $2 \mathrm{M}-\mathrm{HCl}$ for $30 \mathrm{~min}$ to denature the DNA. The sections were blocked with normal horse serum and then treated with mouse monoclonal anti-BrdU (Boehringer-Mannheim, Indianapolis, IN, USA) for $1 \mathrm{~h}$ at room temperature. After washing with phosphate-buffered saline ( $50 \mathrm{mM}$-sodium phosphate, $\mathrm{pH} 7.4,200 \mathrm{mM}-\mathrm{NaCl}$ ), the sections were incubated with a biotin-conjugated goat antimouse immunoglobulin G (Vector Laboratories, Burlingame, CA, USA) for $30 \mathrm{~min}$ at room temperature. Horseradish peroxidase complex reagents (Vector Laboratories) were used to localize the secondary antibody. The $3,3^{\prime}$-diaminobenzidine substrate was used in the colour reaction. More than 500 cells were counted in randomly selected areas of three tissue sections from each dam to measure the DNA synthesis labelling index. The labelling index was defined as the ratio BrdU-labelled cells: total number of cells counted, and was expressed as a percentage.

\section{Apoptosis in situ by end-labelling}

Five randomly selected rats from each dietary group were killed during late lactation (day 20). Apoptotic mammary epithelial cells were essentially detected according to the terminal deoxynucleotidyl transferase (TdT)-mediated deoxyuridine triphosphate-biotin nick end labelling (TUNEL) procedure described by Gavrieli et al. (1992). Briefly, paraffin-embedded tissue was sectioned at $5 \mu \mathrm{m}$ and adhered to glass slides. The sections were deparaffinized and rehydrated for in situ specific labelling to fragmented DNA. Nuclei of tissue sections were stripped of proteins by incubation with $20 \mathrm{mg} / 1$ proteinase $\mathrm{K}$ (EC 3.4.21.64) for $30 \mathrm{~min}$. Endogenous peroxidase was inactivated with $30 \mathrm{ml} / 1 \mathrm{H}_{2} \mathrm{O}_{2}$-methanol $(1: 49, \mathrm{v} / \mathrm{v})$ for $30 \mathrm{~min}$. After rinsing with distilled water, the sections were 
immersed in a buffer ( $30 \mathrm{mM}$-Tris, $\mathrm{pH} 7 \cdot 2,140 \mathrm{mM}$-sodium cacodylate, $\left.1 \mathrm{mM}-\mathrm{CoCl}_{2}\right)$ containing TdT $(0.3$ units $/ \mu \mathrm{l})$ and 1 mM-biotinylated dUTP (Clontech, Palo Alto, CA, USA) and then incubated in a humid atmosphere at $37^{\circ}$ for $60 \mathrm{~min}$. On termination of the reaction the sections were treated with the avidin-biotin complex (Vectastain Elite $\mathrm{ABC}$ kit; Vector Laboratories). A 3,3'-diaminobenzidine substrate was used in the colour reaction. Rat intestinal sections were used as the positive control. The apoptotic cell labelling index was calculated after counting more than 500 nuclei in randomly selected areas of three tissue sections from each dam. The labelling index was defined as the ratio positive nuclei : total number of nuclei counted, and was expressed as a percentage.

\section{RNA extraction and dot and Northern blot analyses}

Total RNA was extracted from mammary tissue of pregnant rats (day 11) by the modified Chomczynski \& Sacchi (1987) method. Briefly, the mammary tissues were pulverized in liquid $\mathrm{N}_{2}$ and homogenized in lysis buffer containing $4 \mathrm{M}$-guanidium thiocyanate, $25 \mathrm{mM}$-sodium citrate, $5 \mathrm{ml} / 1$ sarcosyl, $0.1 \mathrm{M}$-2-mercaptoethanol. The homogenate was extracted with phenol and chloroform. Total RNA in the aqueous phase was precipitated with isopropanol and sodium acetate, $\mathrm{pH} 4 \cdot 2$, and dissolved in diethyl pyrocarbonate-treated distilled deionized water. For dot blotting, total RNA from individual mammary tissues was serially diluted twofold and dotted directly onto nylon membranes as previously described (Baik et al. 1992). For Northern blotting, poly $(\mathrm{A})^{+}$RNA was isolated from pooled total RNA using oligo deoxythymidine cellulose columns (5 Prime $\rightarrow 3$ Prime Inc., Boulder, CO, USA). Poly(A) ${ }^{+}$ RNA ( $6 \mu \mathrm{g}$ per lane) was fractionated by electrophoresis on agarose gels $(12 \mathrm{~g} / \mathrm{l})$ containing $2 \cdot 2 \mathrm{M}$-formaldehyde and transferred to nylon membranes.

The membranes were baked for 30 minutes at $80^{\circ}$ and prehybridized for $3 \mathrm{~h}$ at $42^{\circ}$ in hybridization buffer containing $500 \mathrm{~g} / 1$ formamide, $6 \mathrm{X}$ Denhardt's solution and $2 \mathrm{ml} / 1$ SDS. The rat ornithine decarboxylase ( $E C$ 4.1.1.17; ODC) cDNA was donated by Dr P.J. Blackshear (Duke University, Durham, NC, USA). The $\gamma$-actin cDNA was obtained from Dr L.H. Kedes (University of Southern California, Los Angeles, CA, USA). The ODC cDNA insert was excised with the restriction enzyme EcoRI, and the $\gamma$ actin cDNA insert was excised with the restriction enzyme BamHI for subsequent labelling. The denatured cDNA probes were labelled with $\left[{ }^{32} \mathrm{P}\right] \mathrm{dATP}$ by random priming method (Multiprime DNA Labeling Systems, Amersham Life Science, Arlington Heights, IL, USA). Hybridization was performed for $17 \mathrm{~h}$ at $42^{\circ}$. The membranes were washed twice at room temperature in a solution containing $5 \mathrm{X}$ sodium chloride-sodium dihydrogen phosphate-EDTA disodium salt (SSPE) and $5 \mathrm{ml} / \mathrm{l}$ SDS, followed by washing twice at $37^{\circ}$ in a solution containing $1 X$ SSPE and $10 \mathrm{ml} / 1$ SDS. The membranes were exposed to X-ray film (Kodak, Rochester, NY, USA) with an intensifying screen at $-70^{\circ}$ for $72 \mathrm{~h}$. The relative intensities of the autoradiograms were quantitated by laser densitometry (Personal Densitometer SI System, Molecular Dynamics, Sunnyvale, CA, USA),

\section{Statistical analysis}

All statistical analyses were performed with SAS/STAT version 6.11, (Statistical Analysis Systems Institute, Cary, NC, USA). Data on food intake and litter weight were analysed using one-way ANOVA with repeated measures. Gene expression and lactation data were analysed with the independent Student's $t$ test for unpaired observations. Pearson's correlation coefficients were used to assess the relationship between selected variables. Differences were considered significant at $P<0.05$.

\section{Results and discussion}

Mammary growth is the major determinant of milk yield capacity and persistency of lactation (Forsyth, 1996). Growth and differentiation of the mammary gland are regulated by various hormones, growth factors, and nutritional factors including the plane of nutrition (Borellini \& Oka, 1989; Imagawa et al. 1990). Several studies have shown that a controlled nutrition regimen imposed during early developmental stages before first parturition can influence significantly mammary growth, differentiation and subsequent lactation performance (Park et al. 1988, 1989, 1997; Peri et al. 1993; Choi et al. 1997). To develop a better understanding of nutritionally-mediated mammary development and lactation, our laboratory has proposed and studied a stair-step compensatory nutrition regimen. This nutrition regimen, a combination of both energy restriction and realimentation, was designed primarily to improve lactation potential by exploiting the characteristics of the compensatory growth phenomenon during peripubertal developmental stages (Park et al. 1988, 1989, 1994a, 1997; Choi et al. 1997).

The theoretical energy intakes of the compensatory nutrition group were $68.8 \%$ and $100 \%$ for energy restriction and re-alimentation phases respectively, with an overall $13.4 \%$ reduction in energy intake compared with the control group. Actual total energy intakes (Table 2) of the compensatory nutrition regimen rats were $68.3 \%$ of the intake of the control rats during the energy restriction phase and $104.2 \%$ of the intake of the control rats during the re-alimentation period. This corresponds to an approximate overall $11 \%$ reduction in energy intake, indicating that energy intakes were regulated as intended by design. Results from earlier studies show consistently that the compensatory nutrition regimen improves efficiency of energy (weight gain/energy intake) of all animal species examined (Park et al. 1987, 1994a; Choi et al. 1997).

Overall lactation performance was improved in the compensatory nutrition regimen group. Average litter weight and milk yield per dam are shown in Table 3. While the initial litter weight and size were not different between groups, the average litter weight on day 15 of lactation was $23 \%$ higher $(P<0.05)$ in the compensatory nutrition group than in the control group. Dams reared on the compensatory nutrition regimen produced $17 \%$ more $(P<0.05)$ milk than did dams on the control diet. Lactation is influenced by many factors, such as nutritional and 
Table 2. Total energy intake of rats on experimental diets $(\mathrm{MJ}) \dagger$

(Mean values with their standard errors; ranges in parentheses)

\begin{tabular}{|c|c|c|c|c|c|}
\hline \multirow{3}{*}{$\begin{array}{l}\text { Nutrition phase } \$ \\
\text { (age, weeks) }\end{array}$} & \multirow[b]{3}{*}{$n \S$} & \multicolumn{4}{|c|}{ Nutrition regimen } \\
\hline & & \multicolumn{2}{|c|}{ Control } & \multicolumn{2}{|c|}{ Compensatory nutrition } \\
\hline & & Mean (Range) & SEM & Mean (Range) & SEM \\
\hline $\begin{array}{l}\text { Energy restriction } \\
(7-10)\end{array}$ & 20 & $\begin{array}{c}5.62 \\
(4.82-6.39)\end{array}$ & 0.08 & $\begin{array}{c}3.84^{*} \\
(3.24-4.51)\end{array}$ & 0.06 \\
\hline $\begin{array}{l}\text { Re-alimentation } \\
(10-14)\end{array}$ & 17 & $\begin{array}{c}7.06 \\
(6.52-7.35)\end{array}$ & 0.04 & $\begin{array}{c}7.36^{\star} \\
(6.88-8.02)\end{array}$ & 0.05 \\
\hline Overall & 17 & $\begin{array}{c}12.68 \\
(11.06-13.94)\end{array}$ & 0.08 & $\begin{array}{c}11 \cdot 20^{*} \\
(10.29-12.63)\end{array}$ & 0.09 \\
\hline
\end{tabular}

Mean values were significantly different from those of the control group, ${ }^{\star} P<0.05$.

$\dagger$ Each value represents total energy intake per rat during the indicated period. Total energy intake $(\mathrm{MJ})=$ total feed intake $(\mathrm{kg}) \times$ digestible energy of experimental diet $(\mathrm{MJ} / \mathrm{kg})$.

$\ddagger$ For details of the nutrition phases, see pp. 177-178.

$\S$ Three rats from each group, which failed to conceive, were removed from the experiment during the re-alimentation phase.

endocrine status, but ultimately it is the number of secretory cells that determines milk yield. Moreover, nutritional status at the time of puberty and during pregnancy is critical to maximal mammary cell proliferation (Wilde et al. 1986; Park et al. 1989; Choi et al. 1997). The increase in lactation performance in the compensatory nutrition group was probably due to the compensatory mammary growth that occurred during the re-alimentation phase; this period encompassed puberty through to late gestation.

Mammary cell proliferation was determined by the extent of BrdU incorporation into DNA (Table 4). Cell proliferation was unchanged between pregnant and early lactating stages in mammary tissues from the compensatory nutrition rats; however, mammary cell proliferation decreased $50 \%(P<0.05)$ from pregnancy to early lactation in tissues of control rats $(5.8 v .2 .9)$. This postpartum decrease in proliferative activity was unexpected since peak cellular proliferation in rat mammary tissues occurs during early gestation and continues through early lactation (Joshi et al. 1986). Mammary cell proliferation rates were 1.4- and 2.7-fold greater in mammary tissue from the compensatory group during pregnant $(P<0.05)$ and early lactating $(P<0.05)$ stages respectively, compared with those from the control group (Table 4). It is possible that accelerated compensatory growth induced during realimentation may alter the level and activities of transcription factors regulating cell proliferation through changes in the hormonal status of the animal. There were no significant correlations between mammary cell proliferation and initial litter size and litter weight in either experimental group.

Table 3. Litter weight and milk yield in rats fed on a compensatory nutrition regimen compared with controls

(Mean values with their standard errors; ranges in parentheses)

\begin{tabular}{|c|c|c|c|c|c|}
\hline \multirow[b]{3}{*}{ Response variable } & \multirow[b]{3}{*}{$m \dagger$} & \multicolumn{4}{|c|}{ Nutrition regimen } \\
\hline & & \multicolumn{2}{|c|}{ Control } & \multicolumn{2}{|c|}{ Compensatory nutrition } \\
\hline & & Mean (Range) & SEM & Mean (Range) & SEM \\
\hline Initial litter size & 12 & $\begin{array}{c}10.9 \\
(7-15)\end{array}$ & 0.6 & $\begin{array}{c}11.5 \\
(8-18)\end{array}$ & 0.6 \\
\hline \multicolumn{6}{|l|}{ Litter weight $(g)$} \\
\hline Initial & 12 & $\begin{array}{c}68.7 \\
(47.1-87.4)\end{array}$ & $4 \cdot 0$ & $\begin{array}{c}71.6 \\
(42.6-106.7)\end{array}$ & 3.9 \\
\hline On day 3 of lactation $\ddagger$ & 12 & $\begin{array}{c}66.7 \\
(53.7-90.2)\end{array}$ & $2 \cdot 6$ & $\begin{array}{c}70.4 \\
(48.2-88.9)\end{array}$ & 3.4 \\
\hline On day 15 of lactation & 7 & $\begin{array}{c}162 \cdot 2 \\
(125 \cdot 2-195 \cdot 0)\end{array}$ & 11.1 & $\begin{array}{c}199.7^{*} \\
(138.5-270.7)\end{array}$ & 12.5 \\
\hline Milk yield $(\mathrm{g}) \S$ & 7 & $\begin{array}{c}19.6 \\
(14.5-25.6)\end{array}$ & 0.6 & $\begin{array}{c}23 \cdot 0^{\star} \\
(15 \cdot 2-31 \cdot 2)\end{array}$ & 0.5 \\
\hline
\end{tabular}

Mean values were significantly different from those of the control group, $P<0.05$.

+ Number of dams.

$\ddagger$ Adjusted to eight pups per dam on day 3 .

$\S$ Milk yield on day 15 of lactation was estimated by the stepwise forward multiple regression equation (Sampson \& Jansen, 1984) as follows: yield $=[0.0322+(0.0667 \times$ weight $)+(0.877 \times$ gain) $] \times 8$, where yield is total milk yield per litter (g); Weight is average pup weight on day 15 of lactation (g); gain is average rate of pup weight gain on day $15(\mathrm{~g} / \mathrm{d})$; and 8 is litter size on day 15 of lactation. 
Table 4. Labelling index of rat mammary cells exhibiting cell proliferation and apoptosis during pregnancy and lactation (\%) $\ddagger$

(Mean values with their standard errors)

\begin{tabular}{|c|c|c|c|c|c|}
\hline \multirow[b]{3}{*}{ Item } & \multirow[b]{3}{*}{$n$} & \multicolumn{4}{|c|}{ Nutrition regimen } \\
\hline & & \multicolumn{2}{|c|}{ Control } & \multicolumn{2}{|c|}{$\begin{array}{l}\text { Compensatory } \\
\text { nutrition }\end{array}$} \\
\hline & & Mean & SEM & Mean & SEM \\
\hline \multicolumn{6}{|l|}{ Cell proliferation } \\
\hline $\begin{array}{l}\text { Mid pregnancy } \\
\text { Early lactation }\end{array}$ & $\begin{array}{l}5 \\
5\end{array}$ & $\begin{array}{l}5.81 \dagger \\
2.90\end{array}$ & $\begin{array}{l}0.02 \\
0.03\end{array}$ & $\begin{array}{l}8 \cdot 30^{*} \\
7 \cdot 81^{*}\end{array}$ & $\begin{array}{l}0.04 \\
0.06\end{array}$ \\
\hline \multicolumn{6}{|l|}{ Apoptosis } \\
\hline Late lactation & 5 & 4.59 & 0.34 & 3.97 & 0.24 \\
\hline
\end{tabular}

Growth hormone and prolactin are associated with the regulation of the expression of ODC (Rillema et al. 1981). The expression of ODC is also sensitive to dietary energy modifications (Maudsley et al. 1976; Baik et al. 1992; Yoshinaga et al. 1993; Park et al. 1994b). ODC, the rate-limiting enzyme in polyamine biosynthesis, is closely correlated with cell proliferation and differentiation (Pegg \& McCann, 1982). The level of ODC mRNA was $24 \%$ greater $(P<0.05)$ in tissues from the compensatory nutrition group than in those from the control group on day 11 of pregnancy (Fig. 1). The expression of ODC may be triggered by elevated levels of growth hormone induced during compensatory growth, thereby affecting the rate of polyamine biosynthesis, and subsequently the synthesis of milk protein in the mammary gland (Oka et al. 1982).

In addition to cell proliferation, lactation performance may also be affected by apoptosis. Apoptosis is a mode of physiological cell death that occurs naturally in rodent mammary tissue during involution (Walker et al. 1989). Milk output decreases gradually, probably because mammary alveolar secretory cells are lost and synthetic activity per cell declines (Knight \& Wilde, 1993; Park \& Jacobson, 1993). The inhibition of apoptosis might prolong secretory cell longevity (Strange et al. 1992; Li et al. 1996).

Apoptosis was determined by specific labelling of DNA breaks in situ (Table 4). While apoptotic mammary cells were detectable in mammary tissues from both groups during late lactation $(20 \mathrm{~d})$, there was no significant $(P>0.05)$ difference between the two dietary treatments. There was also no significant correlation between apoptotic cell numbers and litter size or litter weight.

\section{Conclusions}

The compensatory nutrition regimen imposed during the peripubertal growth phase stimulated the expression of ODC, a gene regulating mammary cell proliferation. Rats on the compensatory nutrition regimen had increased cell proliferation and enhanced lactation performance.

In addition to improving lactation performance, our compensatory nutrition regimen may offer opportunities in (a) 1

2

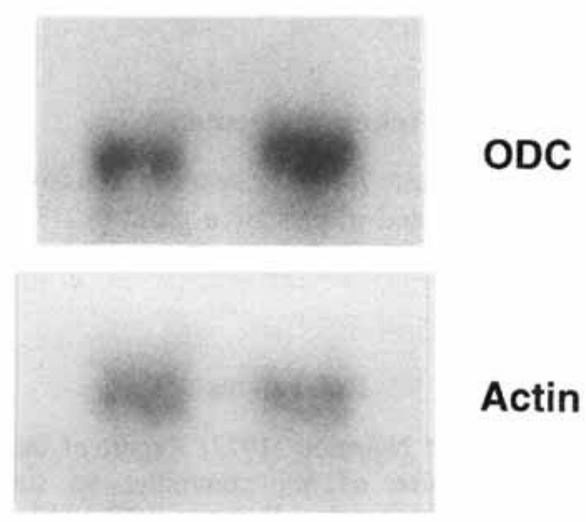

(b)

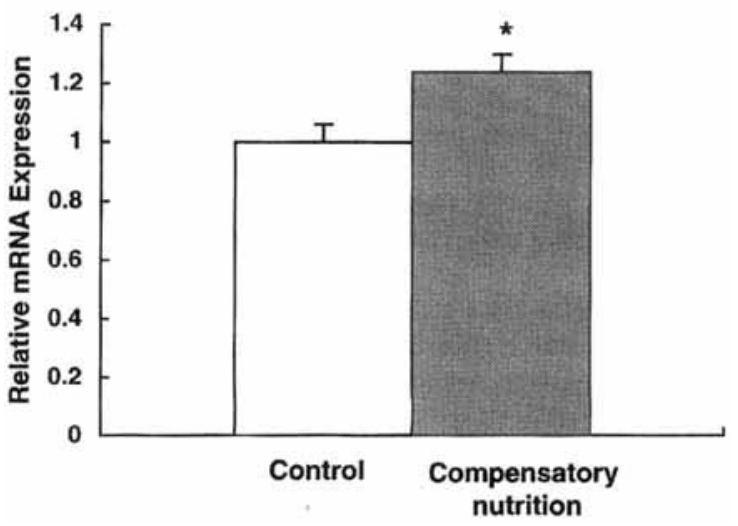

Flg. 1. The expression of ornithine decarboxylase (ODC) mRNA in rat mammary tissues during pregnancy (day 11). (a) Pooled poly $(A)^{+}$RNA $(6 \mu \mathrm{g}$ per lane) was fractionated on a denaturing agarose gel $(12 \mathrm{~g} / \mathrm{l})$, transferred to a nylon membrane, and hybridized with ODC CDNA. Lane 1, control; lane 2, compensatory nutrition group. The result of hybridizing the same membrane with a $\gamma$-actin probe is shown as a reference for RNA loading. (b) Results of dot blot analysis. Total RNA extracted from mammary tissues of individual rats was dotted onto a nylon membrane and hybridized with ODC cDNA. The signals on the autoradiograms were quantitied by laser densitometry. The data shown are arbitrary densitometric unit means $(n 5)$ with their standard errors represented by vertical bars. Mean value for the compensatory nutrition group was significantly different from the control value, ${ }^{*} P<0.05$. 
the development of breast cancer prevention strategies for young adolescent women. DeWaard \& Trichopoulos (1988) hypothesized that breast cancers are most likely to occur between the onset of puberty and the birth of the first baby. Mammary tissue is sensitive to cancer induction during peripubertal development because of the high degree of cell proliferation. On the other hand, the stimulation of rapid growth and fuller differentiation of parenchyma tissue of mammary gland during gestation inhibits tumourigenesis (Russo \& Russo, 1986, 1995). The extent of the mammary epithelial cell proliferation and differentiation depends largely on nutritional status (DeWaard \& Trichopoulos, 1988; Park \& Jacobson, 1993). Our compensatory nutrition regimen can not only enhance the degree of mammary differentiation, but can curtail the span of time between the onset of mammary development and fully differentiated mammary tissues. Thus, the critical mammary growth period sensitive to cancer induction may be shortened.

\section{Acknowledgements}

The authors thank Julie Berg for secretarial assistance. This research was supported in part by a grant (92-37208-8122) from the US Department of Agriculture.

\section{References}

American Institute of Nutrition (1977) Report of the American Institute of Nutrition ad hoc committee on standards for nutritional studies. Journal of Nutrition 107, 1340-1348.

Baik MG, Harrold RL, Choi CB, Slanger WD, Sung CK \& Park CS (1992) Energy restriction and testosterone implants alter ornithine decarboxylase gene expression in kidney of female rats. Journal of Nutrition 122, 1056-1061.

Barash H, Bar-Meir Y \& Bruckental I (1994) Effect of low-energy diet followed by a compensatory diet on growth, puberty and milk production in dairy heifers. Livestock Production Science 39, 263-268.

Borellini F \& Oka T (1989) Growth control and differentiation in mammary epithelial cells. Environmental Health Perspectives 80, 85-99.

Choi YJ, Han IK, Woo JH, Lee HJ, Jang K, Myung KH \& Kim YS (1997) Compensatory growth in dairy heifers: the effect of a compensatory growth pattern on growth rate and lactation performance. Journal of Dairy Science 80, 519-524.

Chomczynski P \& Sacchi N (1987) Single-step method of RNA isolation by acid guanidium thiocyanate-phenol-chloroform extraction. Analytical Biochemistry 162, 156-159.

DeWaard F \& Trichopoulos D (1988) A unifying concept of the aetiology of breast cancer. International Joumal of Cancer 41 , 666-669.

Forsyth IA (1996) The insulin-like growth factor and epidermal growth factor families in mammary cell growth in ruminants: action and interaction with hormones. Joumal of Dairy Science 79, $1085-1096$.

Gavrieli Y, Sherman Y \& Ben-Sasson SA (1992) Identification of programmed cell death in situ via specific labeling of nuclear DNA fragmentation. Journal of Cell Biology 119, 493--501.

Imagawa W, Bandyopadhyay GK \& Nandi S (1990) Regulation of mammary epithelial cell growth in mice and rats. Endocrine Reviews 11, 494-523.
Joshi K, Ellis JTB, Hughes CM, Monaghan P \& Neville AM (1986) Cellular proliferation in the rat mammary gland during pregnancy and lactation. Laboratory Investigation 54, 52-61.

Knight CH \& Wilde CJ (1993) Mammary cell changes during pregnancy and lactation. Livestock Production Science 35, 3-19.

Li M, Hu J, Heermeier K, Hennighausen L \& Furth PA (1996) Apoptosis and remodeling of mammary gland tissue during involution proceeds through p53-independent pathways. Cell Growth and Differentiation 7, 13-20.

Maudsley DV, Leif J \& Kobayashi Y (1976) Ornithine decarboxylase in rat small intestine: stimulation with food or insulin. American Journal of Physiology 231, 1557-1561.

Nelson TS, May MA \& Miles RD (1974) Digestible and metabolizable energy content of feed ingredients for rats. Journal of Animal Science 38, 554-558.

Oka T, Perry JW \& Terada N (1982) The regulatory function of spermidine in hormonal control of the development of mouse mammary gland in culture. Federation Proceedings 41, 30733077.

Park CS, Baik MG, Keller WL, Berg IE \& Erickson GM (1989) Role of compensatory growth in lactation: a stair-step nutrient regimen modulates differentiation and lactation of bovine mammary gland. Growth, Development and Aging 53, 159-166.

Park CS, Baik MG, Keller WL \& Slanger WD (1994a) Dietary energy restriction-mediated growth and mammary development in rats. Journal of Animal Science 72, 2319-2324.

Park CS, Choi CB, Baik MG \& Keller WL (1994b) Modulation of expression of fos and Ha-ras oncogene and ornithine decarboxylase activity in mammary gland and liver of young female rats by the absence of dietary lipotropes. Journal of Dairy Science 77, 2214-2220.

Park CS, Choi YJ, Keller WL \& Harrold RL (1988) Effects of compensatory growth on milk protein gene expression and mammary differentiation. FASEB Journal 2, 2619-2624.

Park CS, Danielson RB, Kreft BS, Kim SH, Moon YS \& Keller WL (1997) Nutritionally-directed compensatory growth enhances lactation potential of developing heifers. Journal of Dairy Science (In the Press).

Park CS, Erickson GM, Choi YJ \& Marx GD (1987) Effect of compensatory growth on regulation of growth and lactation: response of dairy heifers to a stair-step growth pattern. Journal of Animal Science 64, 1751-1758.

Park CS \& Jacobson NL (1993) The mammary gland and lactation: In Duke's Physiology of Domestic Animals, 11th ed. Ithaca, NY: Cornell University Press.

Pegg AE \& McCann PP (1982) Polyamine metabolism and function. American Journal of Physiology 243, C212-C221.

Peri I, Gertler A, Bruckental I \& Barash H (1993) The effect of manipulation in energy allowance during the rearing period of heifers on hormone concentrations and milk production in first lactation cows. Journal of Dairy Science 76, 742-751.

Rillema JA, Wing LY \& Cameron CN (1981) Effect of various concentrations of prolactin and growth hormone on the magnitude of stimulation of RNA synthesis, casein synthesis, and ornithine decarboxylase activity in mouse mammary gland. Hormone Research 15, 133-140.

Russo J \& Russo IH (1986) Influence of differentiation and cell kinetics on the susceptibility of rat mammary gland to carcinogenesis. Cancer Research 40, 2677-2687.

Russo J \& Russo IH (1995) The etiopathogenesis of breast cancer prevention. Cancer Letters 90, 81-89.

Sampson DA \& Jansen GR (1984) Measurement of milk yield in the lactating rat from pup weight and weight gain. Journal of Pediatric Gastroenterology and Nutrition 3, 613-617.

Strange R, Li F, Saurer S, Burkhardt A \& Friis RR (1992) Apoptotic cell death and tissue remodeling during mouse mammary gland involution. Development 115, 49-58. 
Walker NI, Bennett RE \& Kerr JFR (1989) Cell death by apoptosis during involution of the lactating breast in mice and rats. American Joumal of Anatomy 185, 19-32.

Weindruch R \& Walford RL (1988) The Retardation of Aging and Disease by Dietary Restriction. Springfield, IL: Charles C. Thomas.
Wilde CJ, Henderson AJ \& Knight CH (1986) Metabolic adaptations in goat mammary tissue during pregnancy and lactation. Journal of Reproduction and Fertility 76, 289-298.

Yoshinaga K, Ishizuka J, Evers BM, Townsend CM Jr \& Thompson JC (1993) Age-related changes in polyamine biosynthesis after fasting and refeeding. Experimental Gerontology 28, 565-572. 